\title{
PENGEMBANGAN MEDIA PEMBELAJARAN ALAT PERAGA PADA MATERI KONVERSI ENERGI GERAK MENJADI ENERGI LISTRIK UNTUK SISWA SMA KELAS X
}

\author{
Faradila Aulia' Alifteria, Mita Anggaryani ${ }^{1}$ \\ ${ }^{1}$ Fisika, Universitas Negeri Surabaya, Surabaya \\ e-mail: faradila.17030184066@mhs.unesa.ac.id, mitaanggaryani@unesa.ac.id
}

\begin{abstract}
Abstrak
Pengembangan media pembelajaran alat peraga pada materi konversi energi gerak menjadi energi listrik merupakan suatu media pembelajaran alat peraga yang berbasis eksperimen. Alat peraga yang dikembangkan digunakan sebagai penunjang pembelajaran untuk memvisualisasikan konsep konversi energi gerak menjadi energi listrik secara lebih jelas dan nyata. Alat peraga yang dikembangkan juga digunakan sebagai alat eksperimen untuk mengetahui faktor-faktor yang dapat mempengaruhi besarnya tegangan keluaran. Penelitian ini bertujuan untuk mendeskripsikan validitas media kognitif untuk menjelaskan konsep konversi energi. Metode penelitian menggunakan ADDIE yang terdiri dari 5 aspek yaitu: analisis, perancangan, pengembangan, implementasi, evaluasi, dengan batasan implementasi pada skala uji laboratorium. Penelitian ini memuat tujuh prosedur pengembangan, yaitu: (1) desain (2) analisis; (3) revisi; (4) uji laboratorium; (5) analisis data; (6) laporan dan (7) validasi. Teknik pengumpulan data yang digunakan adalah uji alat peraga dan uji validasi. Data yang telah diperoleh kemudian dianalisis dengan menggunakan analisis hasil tes alat peraga dan validitas alat peraga menggunakan skala likert yang divalidasi oleh dua orang dosen ahli, dua orang guru fisika SMA dan dua alumni program studi pendidikan fisika. Kesimpulan dari analisis dan pembahasan uji alat peraga menunjukkan bahwa alat peraga dapat mengubah energi dari gerak menjadi energi listrik mengikuti teori yang diajarkan. Beberapa faktor yang menunjukkan gejala konversi energi gerak menjadi energi listrik, sehingga cocok digunakan sebagai alat peraga dan alat praktikum fisika pada materi konversi energi kelas X SMA. Hasil uji validitas menunjukkan bahwa alat peraga layak digunakan dengan hasil validasi $90 \%$ (sangat valid).
\end{abstract}

Kata kunci: Alat Peraga, Konversi Energi, Validitas

\begin{abstract}
The development of learning media for teaching aids on the conversion of motion energy into electrical energy is an experiment-based learning media. The teaching aids developed are used to support learning to visualize the concept of converting energy from motion to electrical energy more clearly and realistically. The teaching aid developed is also used as an experimental tool to determined the factors that can affect the magnitude of the output voltage. This study aims to described the validity of cognitive media to explained the concept of energy conversion. The research method applied ADDIE, which consists of 5 aspects, namely: analysis, design, development, implementation, evaluation, with implementation limitations on a laboratory trial scale. The research contained of seven development procedures, namely: (1) design (2) analysis; (3) revision; (4) laboratory trials; (5) data analysis; (6) reports and (7) validation. The data that has been obtained are then analyzed using analysis of the results of the test props and the validity of the teaching aids using a Likert scale which is validated by two expert lecturers, two high school physics teachers and two alumni of the physics education study program. The conclusion of the analysis and discussion of the test props shows that the props can convert energy from motion to electrical energy following the taught theory. Several factors indicate a symptom of the conversion of motion energy into electrical energy, so it is suitable to be used as a teaching aid and a physics practicum tool in the energy conversion material of class $X$, Senior High School. The validity test results showed that the teaching aid is suitable for use with the validation results of $90 \%$ (very valid).
\end{abstract}

Keywords : Props, Energy Conversion, Validity 


\section{Pendahuluan}

Hal terpenting dan utama sebagai tolak ukur kemajuan bangsa ialah pendidikan. Karena melalui pendidikan kualitas pola pikir sumber daya manusia tersebut dapat ditingkatkan. Indonesia masih sangat membutuhkan inovasi dan telaah pada dunia pendidikan. Proses belajar dan kegiatan utama menjadi suatu hal yang penting dalam sebuah dunia pendidikan. Sebagai fasilitator, guru memiliki tanggung jawab untuk mendesain secara sengaja agar pembelajaran yang dilakukan dapat berjalan secara sistematis dan dapat tercapainya kesinambungan dengan siswa yang dalam proses pembelajaran merupakan subjek pembelajaran (Fathurrohman dan Sutikno, 2011).

Kriteria pembelajaran Kurikulum 2013 memusatkan kegiatan pembelajaran pada siswa (student centered) dengan penekanan pada pemahaman materi dan penguasaan keterampilan pada saat pembelajaran, bukan hanya hasil akhir dari siswa saja. Kurikulum 2013 dirancang agar siswa dapat diberi pengalaman belajar secara luas sebagai pengembangan kemampuan bersikap, menguasai pengetahuan, mampu berpikir kritis dan mampu memecahkan masalah pengetahuan (problem solving). Kurikulum 2013 menggunakan pendekatan saintifik dengan tujuan mengembangkan aspek kemampuan dan keterampilan dalam hal bertanya, mengamati, mencoba, menalar dan mengkomunikasikan. Model pembelajaran yang sangat relevan dengan tujuan tersebut yaitu: inkuiri Terbimbing, pembelajaran berbasis proyek, pembelajaran berbasis pemecahan masalah dan pembelajaran kolaboratif (Mukminan, 2013). Salah satu pendekatan yang mampu membantu siswa dalam mencapai tujuan kurikulum 2013 ialah pendekatan saintifik (scientific approach). Pendekatan saintifik khususnya pada keterampilan proses sains, siswa mampu memahami berbagai fenomena dan gejala serta hubungan antara satu sama lain secara mendalam dan mampu mengaitkan konsep yang dipelajari dengan kenyataan yang terjadi di lingkungan (Kementerian Pendidikan dan Kebudayaan, 2013). Menurut Putri dan Kurniawati (2015) proses pembelajaran dikategorikan sebagai suatu proses komunikasi, dengan adanya proses penyampaian informasi dari sumber informasi kepada penerima informasi melalui media tertentu. Komponen-komponen dalam proses komunikasi meliputi sebuah informasi, sumber informasi, saluran atau media dan penerima informasi. Informasi yang disampaikan merupakan isi pembelajaran yang terdapat pada kurikulum. Sumber Informasi yang dapat digunakan antara lain guru, siswa lain, buku, media penunjang pembelajaran ataupun alat peraga.

Pada pembelajaran fisika memiliki suatu tujuan utama pada aspek pemahaman, penerapan konsep, pelatihan dan pengembangan kinerja ilmiah (Jihad, 2008). Pada aspek pemahaman dan penerapan konsep diperoleh melalui buku bacaan serta informasi yang diberikan oleh guru pada saat proses pembelajaran. Aspek pelatihan dan pengembangan kinerja ilmiah diperoleh melalui proses ilmiah yang terdapat pada suatu kegiatan praktikum. Pada Permendiknas No. 41 tahun 2007, mencantumkan bahwa dalam pelaksanaan pembelajaran kegiatan percobaan di laboratorium guru memiliki peran yang penting sebagai fasilitator siswa. Menurut Permendikbud No.70 tahun 2013, guru hanya berperan sebagai pembimbing dalam proses pembelajaran yang selanjutnya siswa dapat meningkatkan keterampilan dan mewujudkan inovasi kreativitas secara pribadi. Guru diharuskan memiliki kemampuan untuk memilih media pembelajaran yang tepat dan sesuai agar siswa mampu mencapai kompetensi yang diharapkan dan mampu menguasai bahan ajar dengan baik.

Dalam proses pembelajaran, media pembelajaran menjadi hal terpenting yang menjadi salah satu faktor tercapainya keberhasilan dalam pembelajaran. Pada saat proses pembelajaran dilaksanakan, siswa akan mudah bosan jika materi yang disampaikan tidak menarik dan akan berimbas pada kurang maksimal hasil yang diperoleh. Hal yang mampu memberikan pengaruh positif pada motivasi dan hasil belajar siswa salah satunya yaitu melalui penggunaan media pembelajaran. Menurut Riyana (2008), sebagai sarana pemberian pengalaman visual kepada siswa, media pembelajaran mampu mendorong motivasi belajar, 
dan membantu siswa dalam memperjelas dan mempermudah pemahaman konsep yang abstrak, mempertinggi retensi belajar dan daya serap siswa.

Sesuai dengan keadaan di lapangan saat ini, alat peraga atau media pembelajaran yang mampu menunjang proses pemahaman konsep dan materi siswa dirasa masih kurang. Alat peraga yang dapat dijadikan sebagai eksperimen atau praktikum, masih sangat minim di sekolah-sekolah. Menurut Fajar (2013), peningkatan hasil belajar siswa pada aspek kompetensi sikap, pengetahuan dan keterampilan dapat ditingkatkan melalui penggunaan alat peraga. Siswa menjadi lebih aktif, kreatif, mandiri, dan menjadikan proses pembelajaran lebih bermakna sehingga kompetensi yang diharapkan mampu dikuasai dengan baik. Berdasarkan hasil penelitian yang telah dilakukan oleh Fajar Swasono (2013), menunjukkan bahwa alat konversi energi efektif digunakan sebagai media pembelajaran baik secara mandiri atau berkelompok. Selain hal tersebut, juga didukung oleh hasil penelitian Siti Komariyah (2017) yang menunjukkan bahwa media pembelajaran dengan model pembangkit listrik tenaga angin berpengaruh pada peningkatan kemampuan berpikir kritis peserta didik pada taraf sedang. Hasil penelitian dari Prasetyarini (2013) mengemukakan bahwa pengembangan alat peraga fisika dapat meningkatkan pemahaman konsep siswa. Pada penelitian yang dilakukan oleh Racy Religia (2017) juga mengemukakan bahwa pengembangan alat peraga dalam pembelajaran fisika mampu meningkatkan hasil belajar siswa dan keterampilan proses sains siswa.

Sejalan dengan uraian tersebut, maka peneliti tertarik untuk mengembangkan sebuah media pembelajaran Konversi Energi Gerak menjadi Energi Listrik (KOGERTIK) yang merupakan alat peraga untuk praktikum. Peneliti akan melakukan penelitian dengan judul "Pengembangan Media Pembelajaran pada Materi Konversi Energi Gerak Menjadi Energi Listrik (KOGERTIK) Untuk Siswa SMA Kelas X" yang dirancang dan diimplementasikan pada suatu studi eksperimen. Perbedaan penelitian pengembangan ini dengan penelitian sebelumnya ialah pada penelitian sebelumnya menggunakan berbagai macam variasi konversi energi dan variabel, sedangkan pada alat peraga ini hanya berfokus pada konversi energi gerak menjadi energi listrik. Jika pada penelitian sebelumnya menggunakan arus listrik sebagai variabel manipulasi, maka pada penelitian ini menggunakan kecepatan angin dan jumlah sudu baling-baling untuk mengetahui pengaruh kecepatan angin, jumlah sudu balingbaling dan lebar permukaan baling-baling pada tegangan output yang dihasilkan. Dengan penggunaan media pembelajaran tersebut diharapkan mampu menjadi solusi dalam mengatasi kesulitan yang dialami siswa dalam memahami konsep-konsep fisika. Tujuan dari penelitian ini untuk mendeskripsikan validitas media pembelajaran pada materi konversi energi gerak menjadi energi listrik dan untuk mendeskripsikan media pembelajaran pada materi konversi energi gerak menjadi energi listrik dapat digunakan untuk menjelaskan konsep Konversi Energi.

\section{Metode}

Jenis penelitian ini yaitu penelitian pengembangan (Research and Development) pada media pembelajaran Konversi Energi Gerak menjadi Energi Listrik (KOGERTIK) dengan menggunakan model ADDIE (Analysis, Design, Development, Implementation, Evaluation). 


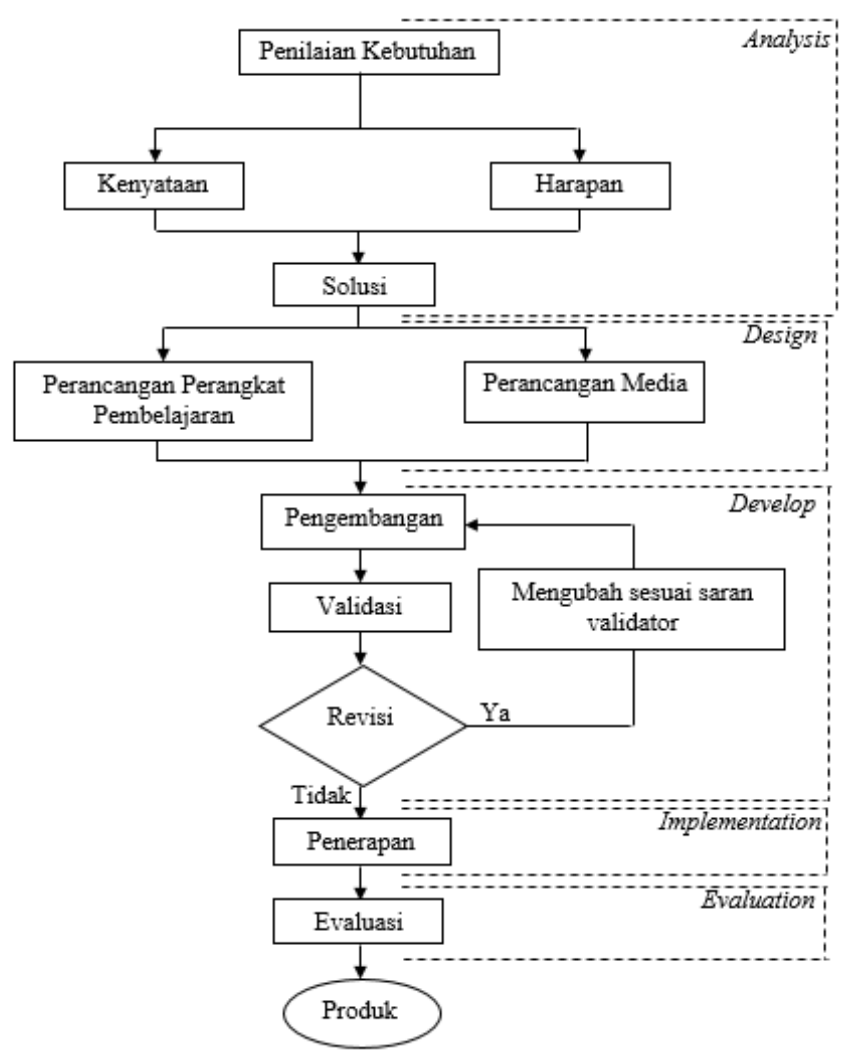

Gambar 1. Rancangan alur penelitian ADDIE (Mulyatiningsih, 2012)

Lokasi pelaksanaan penelitian di jurusan Fisika FMIPA Universitas Negeri Surabaya. Metode uji pada penelitian ini uji coba alat peraga dan validasi ahli. Teknik analisis data yang digunakan ialah analisis deskriptif kuantitatif yang meliputi analisis hasil uji coba alat dan analisis validasi ahli.

Metode uji coba alat digunakan untuk memperoleh data awal untuk mengetahui ketelitian dan keakuratan alat. Prosedur uji coba alat mengikuti prosedur kerja ilmiah di laboratorium yang meliputi: perumusan masalah, perumusan hipotesis, penentuan variabel, pengambilan dan pencatatan data, analisis data, dan kesimpulan. Analisis data difokuskan pada hubungan variabel manipulasi dan respon. Dalam hal ini variabel manipulasi meliputi banyak baling-baling, ukuran sudu, dan kuat lemahnya angin penggerak baling-baling. Sedangkan variabel respon ditunjukkan oleh besaran nilai tegangan yang terukur oleh Avometer pada alat peraga.

Metode validasi ahli digunakan untuk mengetahui kelayakan dan kevalidan alat peraga yang telah dibuat. Validasi dilakukan oleh dua orang dosen ahli media pembelajaran fisika, dua orang guru fisika SMA yang telah memiliki pengalaman mengajar kurang lebih lima tahun, dan dua orang pengembang media pembelajaran berbasis alat peraga yang juga merupakan alumni program studi pendidikan fisika. Validator memberikan penilaian alat peraga berdasarkan rubrik penilaian validasi yang telah disediakan. Penilaian Analisa Validasi dilakukan untuk menganalisis setiap aspek pada media pembelajaran Konversi Energi Gerak menjadi Energi Listrik yang meliputi materi dan media, persentase dari lembar validasi ini pada skala 1 sampai 5 yang diperoleh berdasarkan perhitungan skala Likert seperti pada Tabel 1 .

Tabel 1. Skala Likert

\begin{tabular}{cc}
\hline Penilaian & Skor \\
\hline Sangat Valid Sekali & 5 \\
\hline Sangat Valid & 4 \\
\hline Valid & 3 \\
\hline Kurang Valid & 2 \\
\hline Kurang Valid Sekali & 1 \\
\hline
\end{tabular}


Dengan aturan presentasi skor sebagai berikut:

$$
P(\%)=\frac{\text { Jumlah skor yang diperoleh }}{\text { Jumlah Skor maksimum }} \times 100 \%
$$

Berikut kriteria penilaian hasil analisis lembar uji validasi:

Tabel 2. Kriteria persentase rating scale

\begin{tabular}{cc}
\hline Persentase Skor & Kriteria \\
\hline $0 \%-20 \%$ & Sangat Kurang \\
\hline $21 \%-40 \%$ & Kurang \\
\hline $\mathbf{4 1 \%}-\mathbf{6 0 \%}$ & Cukup \\
\hline $\mathbf{6 1 \%}-\mathbf{8 0} \%$ & Baik/Valid \\
\hline $\mathbf{8 1 0 0} \%$ & Sangat Baik/Sangat Valid \\
\hline & Sumber: Riduwan (2015)
\end{tabular}

Berdasarkan kriteria tersebut, media pembelajaran dalam penelitian ini dapat dikatakan memenuhi kriteria apabila persentasenya $\geq 61 \%$ atau dalam kategori baik atau valid, sehingga layak untuk digunakan dalam proses pembelajaran.

\section{Hasil dan Pembahasan}

Hasil penelitian pengembangan yang telah dilakukan adalah berupa alat peraga konversi energi gerak menjadi energi listrik yang dijabarkan dengan menggunakan model $A D D I E$, yaitu Analysis (Analisis), Design (Desain), Development (Pengembangan), Implementation (Implementasi) dan Evaluation (Evaluasi). Berikut merupakan hasil dari setiap tahap penelitian pengembangan yang telah dilakukan:

\section{Analisis}

1.1 Analisis Materi

Pada tahap analisis materi yang dilakukan pada sub materi konversi energi yaitu konversi energi gerak menjadi energi listrik terdapat dua variabel yang diamati yaitu, tegangan output dan kecepatan angin. Berdasarkan analisis materi tersebut peneliti dapat menentukan alat peraga yang akan dikembangkan ialah alat peraga konversi energi gerak menjadi energi listrik dengan angin sebagai sumber energi gerak.

\subsection{Analisis Kurikulum}

Pada tahap analisis kurikulum dilakukan pada kurikulum 2013 revisi 2017. Berikut adalah hasil analisis kurikulum 2013 yang telah dilakukan:

a. Pada kurikulum 2013 diharapkan kompetensi lulusan memiliki kemampuan soft skills dan hard skills secara seimbang yang meliputi beberapa aspek seperti keterampilan, pengetahuan, kompetensi dan sikap.

b. Pembelajaran pada kurikulum 2013 menekankan pada student centered yang menjadikan guru sebagai pembimbing dan fasilitator.

c. Pembelajaran kurikulum 2013 memiliki ciri pendekatan saintifik dengan tujuan megembangkan aspek kemampuan dan keterampilan dalam mengamati, mencoba, bertanya, menalar serta mengkomunikasikan.

d. Pada kurikulum 2013 harus melibatkan teknologi informasi dan komunikasi yang digunakan untuk media pembelajaran sebagai penunjang proses belajar mengajar bagi siswa.

\subsection{Analisis Kebutuhan}

Pada tahap analisis kebutuhan yang telah dilaksanakan dapat diketahui bahwa alat peraga yang dikembangkan sesuai dengan kebutuhan sekolah, yaitu sebagai penunjang penjelasan dan pemahaman konsep pada sub materi konversi energi gerak menjadi energi listrik.

\section{Desain}




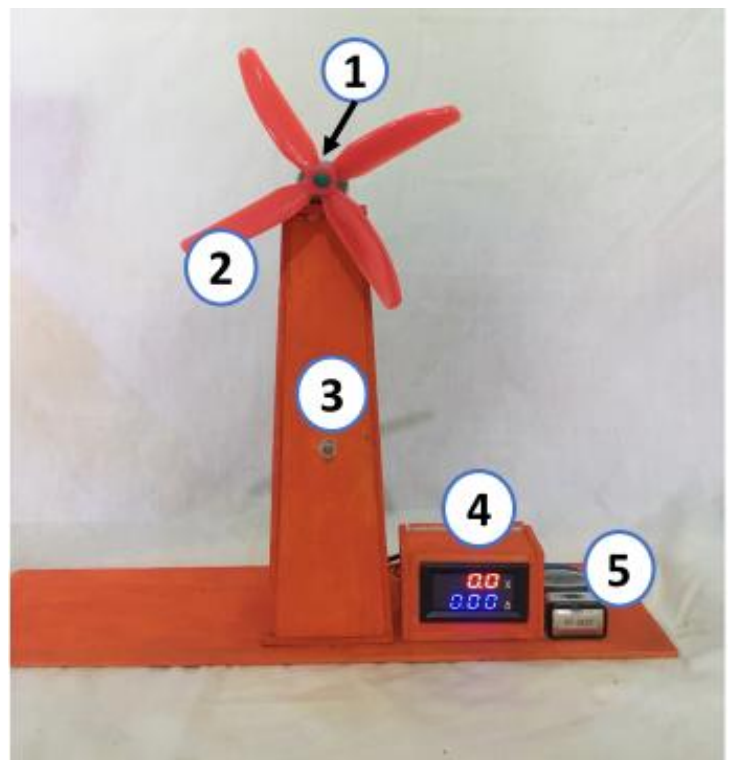

Gambar 2. Alat peraga konversi energi gerak menjadi energi listrik (KOGERTIK)

Tabel 3. Komponen alat peraga KOGERTIK

\begin{tabular}{cl}
\hline No Gambar & \multicolumn{1}{c}{ Keterangan Gambar } \\
\hline $\mathbf{1}$ & Generator DC 6-12V \\
$\mathbf{2}$ & Baling-baling plastik \\
\hline $\mathbf{3}$ & Lampu LED \\
\hline $\mathbf{4}$ & Modul Voltmeter dan Amperemeter Digital \\
\hline $\mathbf{5}$ & Baterai 9V \\
\hline
\end{tabular}

Dari setiap komponen yang digunakan pada alat peraga konversi energi gerak menjadi energi listrik, masing-masing memiliki fungsi dan peranan sebagai berikut:

- Generator DC 6-12V: Pada penelitian ini menggunakan generator DC 6-12V sebagai konverter energi gerak menjadi energi listrik.

- Baling-Baling Plastik: Sebagai penangkap angin yang dihasilkan oleh kipas angin dan sebagai penggerak generator DC 6-12V.

- Lampu LED: Berfungsi sebagai indikator adanya konversi energi gerak menjadi energi listrik dan lampu berperan sebagai bentuk energi listrik.

- Modul Voltmeter dan Amperemeter Digital: Sebagai penunjuk besar tegangan output yang dimiliki lampu LED pada saat energi gerak diubah menjadi energi listrik.

- Baterai 9V: Sebagai catu daya untuk menyalakan Modul voltmeter dan amperemeter digital.

Selain desain fisik alat peraga, pada penelitian pengembangan ini juga terdapat desain rangkaian komponen-komponen yang digunakan, yang divisualisasikan sebagai berikut: 


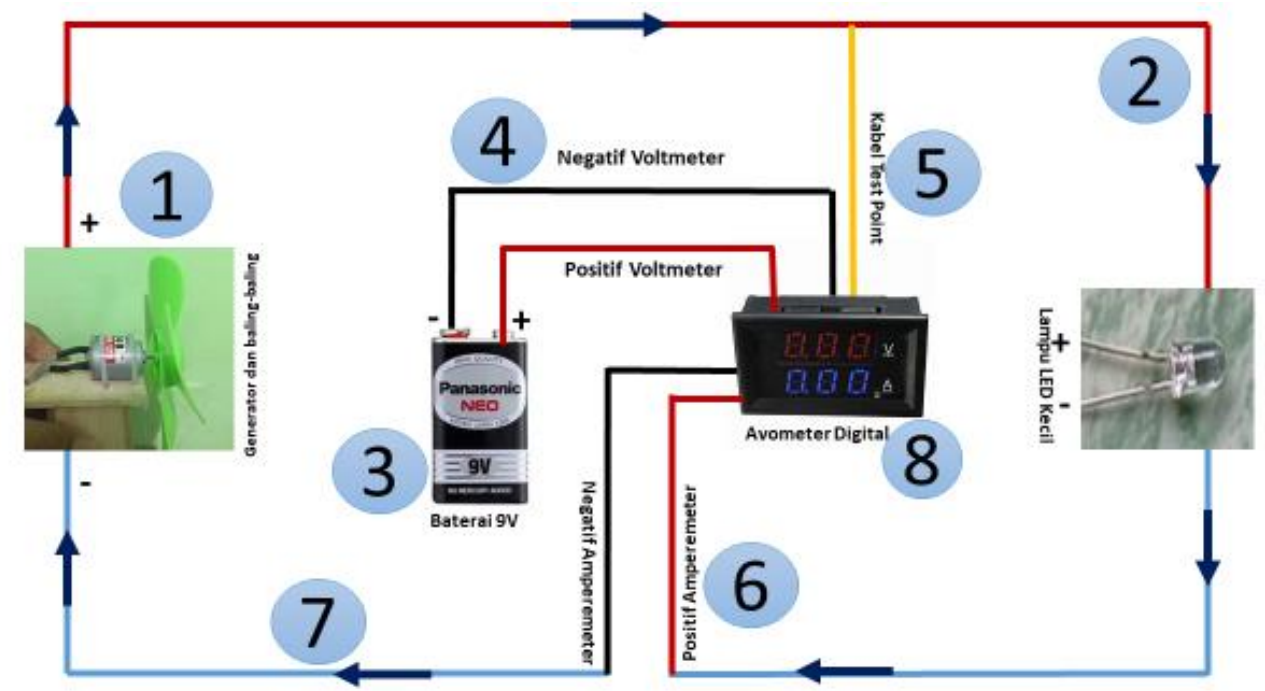

\section{Keterangan}

Gambar 3. Rangkaian komponen dan arah arus alat peraga

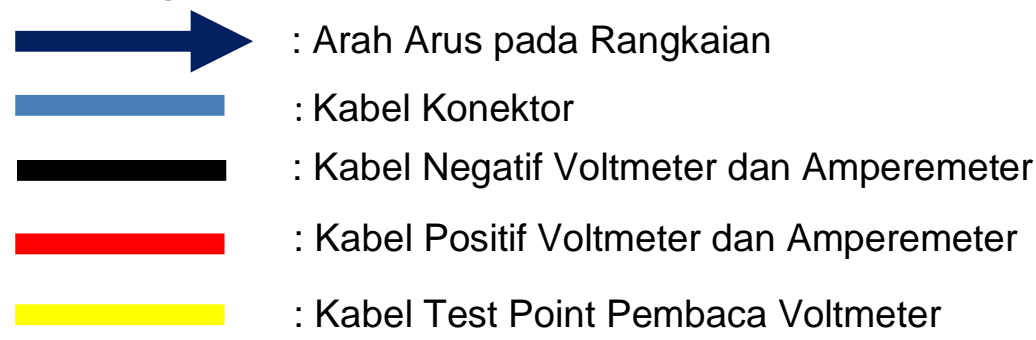

a) Baling-baling berputar karena adanya sumber energi gerak dari angin, hal tersebut menyebabkan motor dalam generator bergerak. Adanya pergerakan pada generator menyebabkan lampu LED menyala, karena pada generator energi gerak dari balingbaling akan diproses dan diubah menjadi energi listrik yang menyalakan lampu LED.

b) Arus listrik mengalir dari kutub positif generator, dan bertemu dengan kutub positif dari Lampu LED.

c) Baterai sebesar 9V disambungkan dengan Modul Voltmeter dan amperemeter digital digunakan sebagai catu daya dari Modul Voltmeter dan amperemeter digital, agar generator bisa bekerja secara optimal untuk mengubah energi gerak menjadi energi listrik.

d) Kabel merah (positif) pada voltmeter digital disambungkan dengan kabel merah (positif) baterai. Kabel hitam (negatif) pada voltmeter digital disambungkan dengan kabel hitam (negatif) baterai. Voltmeter digital dipasang secara paralel dengan rangkaian.

e) Kabel Kuning (testpoint) disambungkan dengan kabel positif pada rangkaian yang menyambungkan generator dengan Lampu LED, agar tegangan yang terbaca pada voltmeter digital merupakan tegangan rangkaian bukan tegangan dari baterai.

f) Kabel merah (positif) pada amperemeter digital disambungkan dengan kabel negatif pada rangkaian yang tersambung dengan kutub negatif output (Lampu LED). Kabel hitam (negatif) pada amperemeter digital disambungkan dengan kabel negatif pada rangkaian yang tersambung dengan kutub negatif catu daya (Generator). Amperemeter digital dipasang secara seri dengan rangkaian.

g) Arus listrik mengalir dari kutub positif generator, dan bertemu dengan kutub positif dari Lampu LED. Selanjutnya diteruskan ke kutub negatif generator.

h) Kegunaan Modul Voltmeter dan amperemeter digital digunakan sebagai penjelas besar tegangan dan besar arus listrik pada saat Lampu LED menyala. Juga digunakan sebagai pembanding besar tegangan dan arus listrik pada saat lampu LED menyala ketika jumlah baling-baling yang digunakan berbeda.

\section{Pengembangan}


Pada tahap pengembangan alat peraga KOGERTIK, peneliti melakukan uji coba alat terlebih dahulu. Pengoperasian alat sesuai dengan prosedur kerja yang tercantum pada lembar kegiatan alat peraga konversi energi gerak menjadi energi listrik yang telah disusun. Tahap ini bertujuan untuk mengetahui kesesuaian alat peraga dengan konsep konversi energi gerak menjadi energi listrik yang telah diajarkan.

Pada uji coba alat peraga konversi energi gerak menjadi energi listrik, terdapat beberapa variabel yang digunakan yaitu sebagai berikut:
a) Variabel Manipulasi
- Kecepatan Kipas angin
- Jumlah Sudu Baling-baling
- Lebar Permukaan Sudu Baling-baling
b) Variabel Kontrol
- Generator DC 6-12V
c) Variabel Respon
- Nyala Lampu LED
- Besar Tegangan Output

Berikut definisi operasional variabel pada pengamatan konversi energi gerak menjadi energi listrik:

a) Kecepatan Kipas Angin

Pada pengamatan ini menggunakan kecepatan kipas angin sebagai variabel manipulasi yang mana terdapat 3 mode kecepatan kipas angin yang berbeda, dengan mode 1 kecepatan rendah $(880 \mathrm{rpm})$, mode 2 kecepatan sedang (1000 rpm) dan mode 3 kecepatan tinggi (1160 rpm).

b) Jumlah Sudu Baling-baling

Jumlah sudu baling-baling yang digunakan pada pengamatan terdapat tiga variasi yang berbeda, yaitu jumlah sudu 2 buah, 3 buah dan 4 buah.

c) Lebar Permukaan sudu baling-baling

Lebar permukaan sudu baling-baling yang digunakan pada pengamatan ini terdapat dua variasi yaitu lebar permukaan sudu baling-baling kecil $(1 \mathrm{~cm})$ dan lebar permukaan sudu baling-baling lebar $(5 \mathrm{~cm})$.

d) Generator DC 6-12V

Generator yang digunakan pada pengamatan ini yaitu generator DC dengan tegangan output sebesar 6-12V.

e) Nyala Lampu LED

Pada pengamatan ini nyala lampu LED digunakan sebagai indikator perubahan energi listrik terdapat tiga kondisi nyala lampu LED yaitu Terang, Redup dan Tidak Menyala.

f) Besar Tegangan Output

Besar tegangan output yang terdapat pada lampu LED pada saat adanya konversi energi gerak menjadi energi listrik ditampilkan oleh Modul Voltmeter dan Amperemeter digital.

Pada tahap uji coba alat, peneliti menguji dengan menggunakan pengukuran berulang sebanyak 10 kali pada tiap manipulasi. Terdapat 3 variasi data yang dihasilkan yaitu pengaruh kecepatan angin terhadap besar tegangan output, pengaruh jumlah sudu baling-baling terhadap besar tegangan output, dan pengaruh luas permukaan sudu baling-baling terhadap besar tegangan output. Uji coba alat dengan menggunakan pengukuran berulang untuk mengetahui konstan atau tidaknya besar tegangan output yang dihasilkan pada saat alat peraga dioperasikan. Hal tersebut juga disebabkan karena adanya rentang variasi besar tegangan output yang dihasilkan pada saat uji coba dilakukan. Pengulangan sebanyak 10 kali sesuai dengan kriteria pengukuran berulang yaitu diulang sebanyak 3 kali atau lebih sehingga data yang didapatkan lebih akurat. Data pengukuran pengulangan dapat dikatakan konstan, dibuktikan dengan variasi data pada tiap pengulangan sama atau selisih maksimal sebesar 
$0,1 \mathrm{~V}$. Data yang ditampilkan pada grafik merupakan hasil dari rata-rata 10 kali pengulangan yang telah dilakukan.

Baling-baling dengan jumlah sudu 2 dengan luas permukaan kecil dinotasikan dalam huruf A. Baling-baling dengan jumlah sudu 3 dengan luas permukaan kecil dinotasikan dalam huruf $B$. Baling-baling dengan jumlah sudu 4 dengan luas permukaan kecil dinotasikan dalam huruf $C$. Baling-baling dengan jumlah sudu 4 dengan luas permukaan besar dinotasikan dalam huruf $D$.

Berikut adalah data hasil uji coba oleh peneliti dalam bentuk grafik:

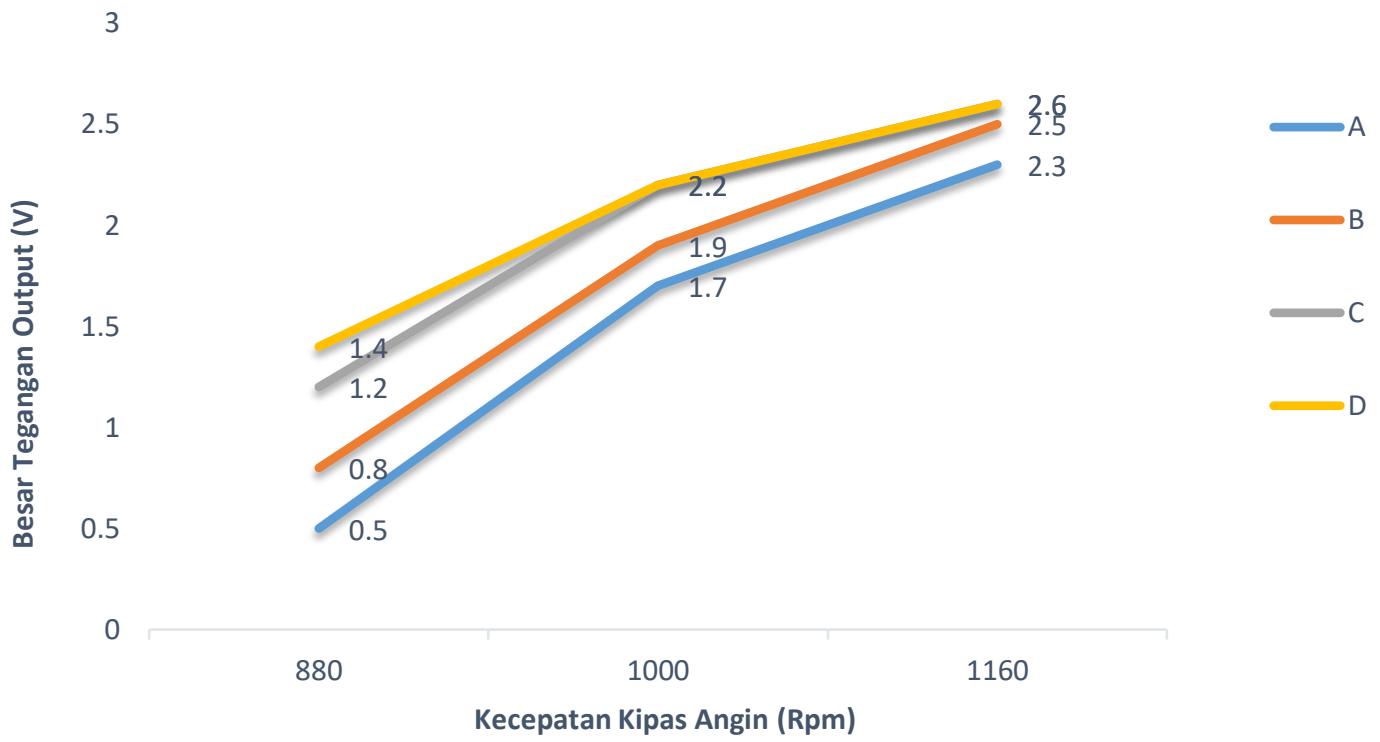

Gambar 4. Grafik pengaruh kecepatan kipas angin terhadap tegangan output pada 4 jenis baling-baling yang berbeda

Berdasarkan grafik diatas dapat dianalisis bahwa tiga kecepatan mode kipas angin dengan kecepatan sebesar $880 \mathrm{rpm}, 1000 \mathrm{rpm}$ dan $1160 \mathrm{rpm}$ berpengaruh terhadap besar tegangan output yang dihasilkan. Melalui tiga mode kecepatan kipas angin tersebut menunjukkan bahwa, energi gerak yang dihasilkan oleh kipas angin dipengaruhi oleh kecepatan dari baling-baling kipas angin yang bergerak. Pada tiap tipe baling-baling memiliki variasi tegangan output, dimana semakin tinggi kecepatan kipas angin yang digunakan, maka semakin tinggi pula besar tegangan output yang dihasilkan. Hal tersebut sesuai dengan konsep hukum kekekalan energi, dimana energi gerak dari kipas angin yang digunakan sebanding dengan energi listrik yang dihasilkan. Sehingga dapat dikatakan bahwa, hubungan antara kecepatan mode kipas angin dengan besar tegangan output yang dihasilkan adalah berbanding lurus. Sehingga dapat dikatakan bahwa alat peraga tersebut sesuai konsep konversi energi yang memenuhi hukum kekekalan energi. Pada pengambilan data alat peraga ini, kipas angin yang digunakan memiliki daya sebesar 55 Watt dan frekuensi sebesar $50 \mathrm{~Hz}$. Kipas Angin yang digunakan memiliki tiga mode kecepatan kipas angin, dimana mode 1 merupakan kecepatan terendah dan mode 3 merupakan kecepatan tertinggi. Dengan rincian kecepatan angin pada satuan rpm yaitu pada mode 1 sebesar $880 \mathrm{rpm}$, pada mode 2 sebesar $1000 \mathrm{rpm}$ dan pada mode 3 sebesar $1160 \mathrm{rpm}$ sesuai dengan rincian yang tertera pada spesifikasi kipas angin. Rentang selisih pada tiap manipulasi data dapat dikategorikan besar yaitu sebesar 0,4-1,2 V. 


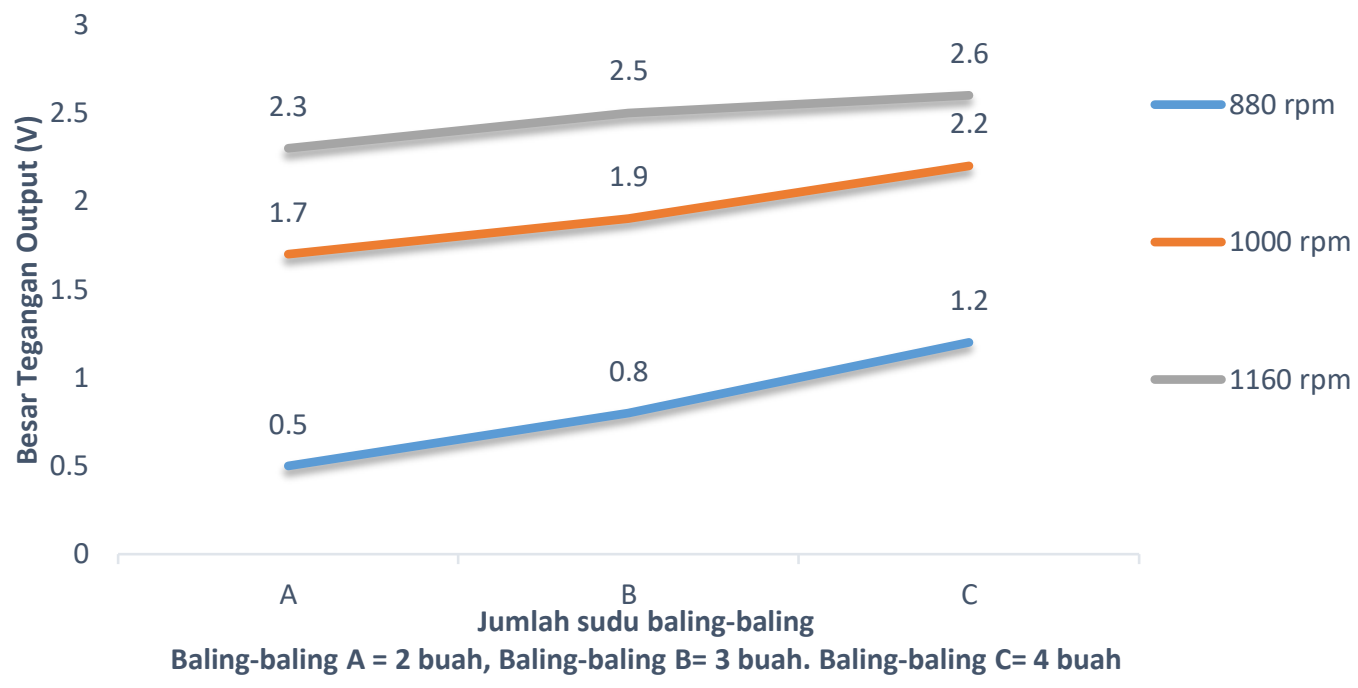

Gambar 5. Grafik hubungan jumlah sudu baling-baling dengan besar tegangan output pada 3 mode kecepatan kipas angin yang berbeda

Berdasarkan hasil dari analisis grafik data yang diperoleh di atas dapat diketahui bahwa jumlah baling-baling berpengaruh terhadap besar tegangan output yang dihasilkan. Pada percobaan ini menggunakan 3 tipe baling-baling dengan luas permukaan yang sama namun jumlah sudu baling-baling yang berbeda yaitu baling-baling A ( 2 buah), baling-baling $B$ (3 buah) dan baling-baling $\mathrm{C}$ (4 buah). Berdasarkan data yang divisualisasikan menjadi grafik, diketahui bahwa semakin banyak jumlah sudu baling-baling yang digunakan, maka semakin besar pula tegangan output yang dihasilkan. Hal tersebut menunjukkan bahwa hubungan antara jumlah sudu baling-baling dengan besar tegangan output yang dihasilkan ialah berbanding lurus atau sebanding. Rentang selisih pada tiap manipulasi data dapat dikategorikan besar yaitu sebesar 0,2-0,5 V.

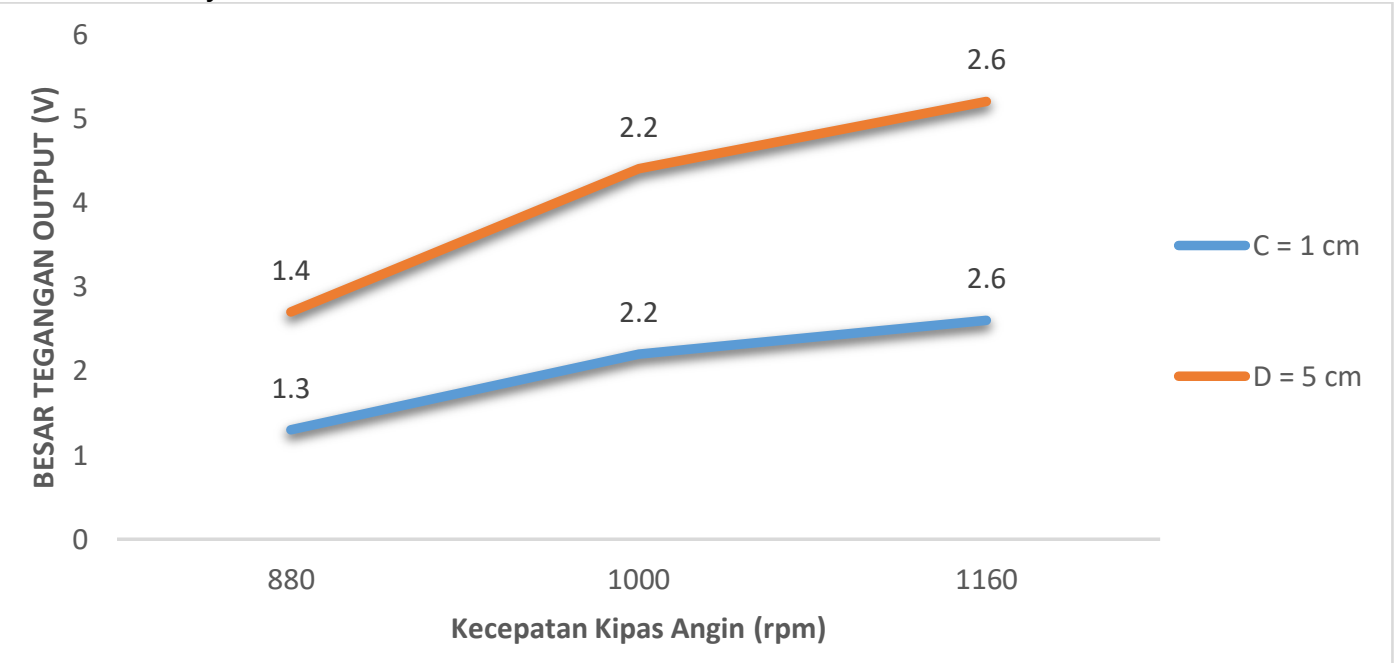

Gambar 6. Grafik hubungan lebar sudu baling-baling terhadap besar tegangan output pada kecepatan kipas angin yang berbeda

Pada uji coba alat peraga juga memanipulasi lebar permukaan sudu baling-baling yang digunakan yaitu lebar permukaan kecil dan lebar, dengan jumlah sudu baling-baling yang sama yaitu 4 buah. C merupakan baling-baling dengan lebar permukaan kecil dan D merupakan baling-baling dengan lebar permukaan lebar. Lebar permukaan sudu baling-baling C sebesar $1 \mathrm{~cm}$ dan lebar permukaan sudu baling-baling $D$ sebesar $5 \mathrm{~cm}$, sehingga dapat dikatakan lebar permukaan sudu baling-baling $D 5$ kali dari lebar permukaan sudu balingbaling $\mathrm{C}$. Berdasarkan analisis hasil uji coba tersebut dapat diketahui bahwa luas permukaan 
baling-baling yang digunakan tidak berpengaruh secara signifikan terhadap besar tegangan output yang dihasilkan. Dapat lihat bahwa rentang selisih besar tegangan output pada tiap manipulasi data hanya sebesar $0-0,1 \mathrm{~V}$. Hal tersebut dapat diartikan bahwa luas permukaan sudu baling-baling tidak berpengaruh terhadap besar tegangan output yang dihasilkan. Nilai tegangan output pada baling-baling dengan luas permukaan sudu kecil dan lebar cenderung sama, dan tidak ada perubahan.

Berdasarkan analisis dari 3 variasi grafik data yang telah dipaparkan maka dapat disimpulkan bahwa faktor yang mempengaruhi perubahan besar tegangan output adalah kecepatan kipas angin dan jumlah sudu baling-baling. Hal tersebut sesuai dengan konsep hukum kekekalan energi yaitu semakin besar energi gerak yang digunakan (energi gerak yang berasal dari kipas angin), maka semakin besar energi listrik yang dihasilkan (energi listrik yang berasal dari tegangan output lampu LED). Sedangkan lebar permukaan sudu baling-baling tidak berpengaruh pada besar tegangan output yang dihasilkan. Sesuai dengan hasil pada uji coba alat peraga, lampu LED dapat menyala dengan tegangan minimum sebesar $2,1 \mathrm{~V}$. Modul voltmeter dan amperemeter digital portable yang digunakan memiliki akurasi pengukuran sebesar $1 \%$ dengan ( \pm 1 digit) sesuai dengan spesifikasi alat tersebut, sehingga taraf ketidakpastian alat tergolong rendah. Berdasarkan hal tersebut dapat menunjukkan adanya konversi energi gerak menjadi energi listrik dibuktikan dengan nyala atau tidaknya lampu LED serta besar tegangan output yang dihasilkan.
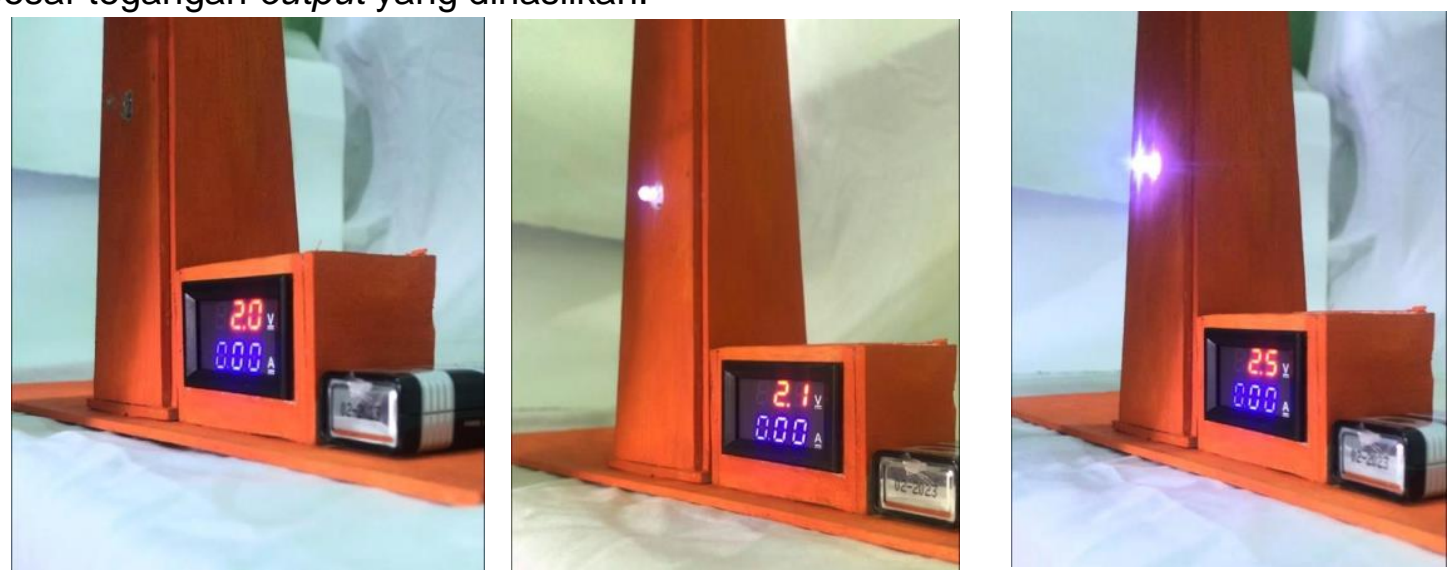

Gambar 7. Dokumentasi uji coba alat peraga KOGERTIK

Setelah dilakukan uji coba alat peraga oleh peneliti, lalu dilakukan validasi oleh enam validator yaitu dosen ahli media dan dosen ahli materi Jurusan Fisika Universitas Negeri Surabaya, dua guru fisika SMA dan dua alumni program studi pendidikan fisika UNESA.

Tabel 4. Demografi Validator

\begin{tabular}{|c|c|c|c|}
\hline Kategori Validator & Pengalaman & Pendidikan & Jumlah \\
\hline Dosen Ahli & $\begin{array}{l}\text { - Mengajar di } \\
\text { jurusan fisika lebih } \\
\text { dari } 15 \text { tahun. } \\
\text { - Membimbing } \\
\text { Skripsi dalam } \\
\text { Rumpun Media } \\
\text { - } \quad \text { Narasumber } \\
\text { Pelatihan Guru }\end{array}$ & $\begin{array}{ll}\text { - } & \text { S1 Pendidikan } \\
& \text { Fisika } \\
\text { - } & \text { S2 Teknik } \\
& \text { Elektro } \\
\text { - } & \text { S2 Fisika }\end{array}$ & 2 \\
\hline Guru Fisika SMA & $\begin{array}{l}\text { - Mengajar Fisika di } \\
\text { SMA lebih dari } 5 \\
\text { tahun. }\end{array}$ & $\begin{array}{l}\text { - S1 Pendidikan } \\
\text { Fisika }\end{array}$ & 2 \\
\hline $\begin{array}{c}\text { Alumni Pendidikan } \\
\text { Fisika }\end{array}$ & $\begin{array}{l}\text { - Mengembangkan } \\
\text { Media } \\
\text { Pembelajaran } \\
\text { Fisika Berbasis } \\
\text { Alat Peraga dan }\end{array}$ & $\begin{array}{l}\text { - S1 Pendidikan } \\
\text { Fisika }\end{array}$ & 2 \\
\hline
\end{tabular}


Kegiatan

Laboratorium

Berdasarkan tabel demografi validator tersebut dapat diketahui bahwa masing-masing kategori validator memiliki kapasitas dan kapabilitas tersendiri dalam melakukan validasi media alat peraga. Dosen ahli dalam hal ini sebagai ahli media dan materi berdasarkan pengalaman dan pengetahuan. Dua guru fisika SMA dalam hal ini sebagai pelaku langsung proses pembelajaran di kelas sehingga mengetahui secara langsung kondisi siswa di kelas. Dua alumni program studi pendidikan fisika dalam hal ini memiliki pengalaman mengembangkan media alat peraga pada penelitian tugas akhir.

Keterangan hasil validasi alat peraga konversi energi gerak menjadi energi listrik dapat dijabarkan sebagai berikut :

Tabel 5. Hasil rekapitulasi penilaian alat peraga

\begin{tabular}{|c|c|c|c|c|c|c|c|c|c|c|}
\hline \multirow[t]{2}{*}{ No } & \multirow[t]{2}{*}{ Aspek Penilaian } & \multicolumn{6}{|c|}{ Penilaian dari Validator } & \multirow[t]{2}{*}{$\Sigma$} & \multirow[t]{2}{*}{ Persentase } & \multirow{2}{*}{$\begin{array}{c}\text { Kategori } \\
\text { Persentase }\end{array}$} \\
\hline & & 1 & 2 & 3 & 4 & 5 & 6 & & & \\
\hline 1 & $\begin{array}{l}\text { Kesesuaian alat } \\
\text { dengan konsep } \\
\text { yang diajarkan. }\end{array}$ & 5 & 5 & 5 & 4 & 5 & 5 & 29 & $96,7 \%$ & $\begin{array}{l}\text { Sangat } \\
\text { Valid }\end{array}$ \\
\hline 2 & $\begin{array}{l}\text { Kemudahan } \\
\text { perawatan alat. }\end{array}$ & 4 & 4 & 5 & 5 & 5 & 5 & 28 & $93,3 \%$ & $\begin{array}{l}\text { Sangat } \\
\text { Valid }\end{array}$ \\
\hline 3 & $\begin{array}{l}\text { Kesesuaian } \\
\text { pembacaan } \\
\text { avometer digital } \\
\text { sebagai indikator } \\
\text { besarnya } \\
\text { tegangan dan } \\
\text { arus listrik pada } \\
\text { lampu LED yang } \\
\text { menyala. }\end{array}$ & 4 & 3 & 4 & 4 & 5 & 5 & 25 & $83,3 \%$ & $\begin{array}{l}\text { Sangat } \\
\text { Valid }\end{array}$ \\
\hline 4 & $\begin{array}{l}\text { Kemudahan } \\
\text { pengoperasian } \\
\text { alat. }\end{array}$ & 5 & 4 & 4 & 5 & 5 & 4 & 27 & $90 \%$ & $\begin{array}{l}\text { Sangat } \\
\text { Valid }\end{array}$ \\
\hline 5 & $\begin{array}{l}\text { Konstruksi alat } \\
\text { aman } \\
\text { peserta didik }\end{array}$ & 5 & 4 & 4 & 5 & 5 & 4 & 27 & $90 \%$ & $\begin{array}{l}\text { Sangat } \\
\text { Valid }\end{array}$ \\
\hline 6 & $\begin{array}{l}\text { Alat memiliki nilai } \\
\text { estetika (warna } \\
\text { dan bentuk) }\end{array}$ & 4 & 4 & 4 & 4 & 5 & 5 & 26 & $86,7 \%$ & $\begin{array}{l}\text { Sangat } \\
\text { Valid }\end{array}$ \\
\hline 7 & $\begin{array}{l}\text { Kemudahan } \\
\text { mencari, } \\
\text { mengambil dan } \\
\text { menyimpan alat. }\end{array}$ & 5 & 4 & 4 & 4 & 5 & 5 & 27 & $90 \%$ & $\begin{array}{l}\text { Sangat } \\
\text { Valid }\end{array}$ \\
\hline & & & & & & & & & $90 \%$ & $\begin{array}{l}\text { Sangat } \\
\text { Valid }\end{array}$ \\
\hline Bord & $\begin{array}{l}\text { Berdasarkan hasil } \\
\text { ai pengajar, dua ora } \\
\text { lan validator untuk pe } \\
\text { menjadi energi listrik } \\
\text { adalah guru fisika SN } \\
\text { sarkan tabel } 4 \text { seluru } \\
\text { asukan yang kemudi } \\
\text { asukan yang pertam }\end{array}$ & & & & & & & & $\begin{array}{l}\text { ia, dua orang } \\
\text { an fisika, terd } \\
\text { alat peraga } \\
\text { dalah dosen } \\
\text { gram studi pe } \\
\text { id. Terdapat } \\
\text { nyempurnaan }\end{array}$ & $\begin{array}{l}\text { uru fisika SMA } \\
\text { pat beberapa } \\
\text { onversi energi } \\
\text { li, validator } 3 \\
\text { ididikan fisika. } \\
\text { berapa saran } \\
\text { oroduk. Saran } \\
\text { liti melakukan } \\
\text { Kedua yaitu }\end{array}$ \\
\hline
\end{tabular}


penambahan prosedur keselamatan kerja pada lembar kegiatan, sehingga peneliti menambahkan keterangan prosedur keselamatan kerja pada lembar kegiatan agar validator dapat memastikan bahwa alat peraga tersebut benar-benar aman digunakan oleh siswa.

Dengan menggunakan perhitungan persentase rata-rata validasi sesuai dengan persamaan (1) pada bagian metode penelitian, diperoleh persentase sebesar $90 \%$. Berdasarkan tabel kriteria persentase rating scale, alat peraga konversi energi gerak menjadi energi listrik yang dikembangkan dapat dikategorikan sangat valid dan layak digunakan sebagai alat peraga untuk menunjang pembelajaran dalam menganalisis konsep konversi energi gerak menjadi energi listrik.

Berdasarkan hasil persentase validasi tersebut, dapat disimpulkan bahwa alat peraga yang telah dikembangkan sangat valid. Hal tersebut ditunjukkan melalui hasil validasi oleh dosen ahli media, alat peraga tersebut valid secara konstruksi media dan sesuai dengan konsep konversi energi gerak menjadi energi listrik. Hasil validasi oleh guru fisika SMA menunjukkan bahwa alat peraga tersebut relevan untuk digunakan sebagai media pembelajaran dikelas dan sebagai alat praktikum untuk siswa. Hasil validasi oleh alumni program studi pendidikan fisika menunjukkan bahwa alat peraga tersebut sudah sesuai dengan prosedur pengembangan alat peraga dan layak untuk dijadikan media pembelajaran fisika berbasis alat peraga dan kegiatan laboratorium.

\section{Evaluasi}

Tahap evaluasi dilakukan berdasarkan hasil pada tahap pengembangan (development) yaitu hasil uji coba alat dan hasil validasi.

Untuk pengembangan alat peraga konversi energi gerak menjadi energi listrik lebih lanjut, maka beberapa hal bisa diperhatikan antara lain generator yang digunakan bisa diubah dengan generator DC dengan besar satuan kilo volt (kV) dan menambahkan perbandingan gear pada generator dan baling-baling agar hasil yang didapatkan dapat lebih terlihat perbedaannya dan rentang perbedaannya juga semakin besar sehingga lebih mudah untuk dianalisis. Modul voltmeter dan amperemeter digital portable akan lebih baik bila dikalibrasi terlebih dahulu menggunakan multimeter digital atau analog yang biasanya digunakan pada eksperimen di laboratorium fisika dasar atau laboratorium elektronika dasar. Selain itu juga bisa menambahkan besar kecepatan dari baling-baling yang digerakkan, sehingga tidak hanya tegangan output saja yang diamati namun juga besar kecepatan dari baling-baling yang digunakan.

Berdasarkan hasil validasi diperoleh persentase sebesar $90 \%$ yang termasuk pada kategori sangat valid. Alat Peraga konversi energi gerak menjadi energi listrik yang dikembangkan memiliki kategori sangat valid dengan batasan pengembangan yaitu memperagakan konversi energi gerak menjadi energi listrik dan mengidentifikasi faktor baling-baling yang dapat mempengaruhi tegangan output yang dihasilkan.

Kelebihan alat peraga KOGERTIK pada penelitian pengembangan ini adalah alat dan bahan yang digunakan mudah didapat sehingga dapat dikonstruksi ulang oleh siswa, rangkaian komponennya pun tergolong mudah dan tidak terlalu rumit. Besar tegangan output yang terbaca juga berasal dari alat berbasis digital sehingga taraf ketidakpastian alat sangat minim. Alat peraga ini memiliki 3 variasi manipulasi data sehingga selain digunakan sebagai alat peraga, juga bisa digunakan sebagai alat praktikum oleh siswa.

Kekurangan alat peraga KOGERTIK pada penelitian pengembangan ini adalah sumber angin yang digunakan masih melalui kipas angin, sehingga selain menyiapkan alat peraga ini, juga perlu menyiapkan kipas angin sebagai sumber energi pada saat pengoperasiannya.

\section{Simpulan dan Saran}

Berdasarkan hasil dari analisis dan pembahasan uji coba alat peraga yang diperoleh pada penelitian pengembangan ini dapat disimpulkan bahwa alat peraga konversi energi gerak menjadi energi listrik mampu menjelaskan konsep konversi energi gerak menjadi energi listrik sesuai dengan teori yang diajarkan, sehingga layak digunakan sebagai alat peraga pembelajaran fisika pada materi konversi energi kelas X SMA. Terdapat tiga variasi manipulasi data yaitu pengaruh kecepatan angin terhadap besar tegangan output, pengaruh jumlah sudu 
baling-baling terhadap besar tegangan output, pengaruh lebar sudu baling-baling terhadap besar tegangan output

Berdasarkan hasil uji validasi oleh dua orang dosen ahli, dua orang guru fisika SMA dan dua orang alumni program studi pendidikan fisika yang melakukan penelitian pengembangan alat peraga. Hasil uji validitas menunjukkan bahwa alat peraga konversi energi gerak menjadi energi listrik yang telah dikembangkan sebagai alat peraga layak digunakan dengan hasil validasi sebesar $90 \%$ yang termasuk dalam kategori sangat valid.

Saran untuk pengembangan selanjutnya ialah kalibrasi modul Voltmeter dan amperemeter digital portable yang digunakan dengan multimeter analog agar amperemeter dari alat peraga juga dapat berfungsi. Dapat melakukan penambahan perbandingan gear agar data yang dihasilkan lebih terlihat perbedaannya. Menambahkan variabel manipulasi yang lain untuk diamati.

\section{Daftar Pustaka}

Arsyad, Azhar. 2005. Media Pembelajaran. Jakarta: PT Raja Grafindo Persada.

Asyhar, Rayanda. 2011. Kreatif Mengembangkan Media Pembelajaran. Jakarta: Gaung Persada (GP) Press Jakarta.

Burns, J. C., Okey, J. R., \& Wise, K. C. 1985. "Development of an integrated process skill test: TIPS II". Journal of Research in Science Teaching. Vol 22 (2): Hal 169-177

Deta,U.A, Suparmi, S.Widha.2013. "Pengaruh Metode Inkuiri Terbimbing dan Proyek, Kreativitas, serta Keterampilan Proses Sains terhadap Prestasi Belajar Siswa". Jurnal Pendidikan Fisika Indonesia. Vol 9 : Hal 28-34.

Didit Widiatmoko. 2012. Metodologi Penelitian Visual, Bandung: Dinamika Komunikasi.

Dong, Y., Bartol, K. M., Zhang, Z. X., \& Li, C. (2017). Enhancing employee creativity via individual skill development and team knowledge sharing: Influences of dual focused transformational leadership. Journal of Organizational Behavior, 38(3), 439 458.

Ennis, R.H. 1985. Goals for a Critical Thinking in Curriculum. Developing Minds A Resource Book for Teaching Thinking. Virginia : Association for Supervisions and Curriculum Development (ASCD).

Fathurrohman, Pupuh Dan M Sobry Sutikno. 2011. Strategi Belajar Mengajar Melalui Penanaman Konsep Umum dan Konsep Islam. Bandung: Refika Aditama

Hamalik, Oemar. 2009. Kurikulum dan Pembelajaran. Jakarta: Bumi Aksara.

Hartini, Sri.dkk . 2018. "Pengembangan Alat Peraga Fisika Energi melalui Perkuliahan Berbasis Project Based Learning". Jurnal Vidya Karya. Vol 33 (1) : Hal 42-50.

Heinich, R.dkk. 1993. Instructional Media (and the new technologies of instruction). New York: Macmillan Publishing.

Huda, Nurul dan Hikmawati Kosim. 2019. TheEffect Of The Contextual Approach Assisted By Teaching Aids On Concept Mastery And The Problem Solving Ability Of Physics Problem.Jurnal Pijar MIPA, Vol. 14 1,Maret 2019:62-72.22.

Husna, Nuril.dkk. 2019. Pengembangan Miniatur Konversi Energi Gerak sebagai Media Pembelajaran Fisika Kontekstual. Jurnal Pendidikan Fisika dan Sains (Gravitasi). Vol 2 (2): Hal $14-22$.

Istambun. 2016. Ebook Mesin Konversi Energi (Online) (https://www.slideshare.net/istambun/ebook-mesin-konversi-energi diakses 2 April 2020).

Jack, G. U. (2013). The Influence of Identified Student and School and School Variables on Students' Science Process Skills Acquisition. Journal of Education and Practice, 4(5), 15-23.

Jalil, R.M., Pratiwi, R., \& Setiawan, B. (2016). Kelayakan Media Alat Peraga Air Mancur Sederhana Untuk Meningkatkan Pemahaman Konsep Pada Materi Hukum Boyle. Pendidikan Sains, 4(3), 1-7

Jihad, Asep dan abdul Haris. 2008. Evaluasi Pembelajaran. Yogyakarta : Multi Presindo. Kementerian Pendidikan dan Kebudayaan. 2013. Implementasi Kurikulum 2013 (Online) (https://www.kemdikbud.go.id/kemdikbud/dokumen/Paparan.com 
diunduh pada 5 Maret 2020).

Kemp, J.E. dan Dayton, D.K. 1985. "Planning and Producing Instruction. Media". New York. Cambridge: Harper \& Row Publishers.

Khan, Muzaffar and Iqbal, Muhammad Zafar. 2011. Effect of Inquiry Lab Teaching Method on the Development of Scientific Skills Through the Teaching of Biology in Pakistan. Language in India, 11(1): 169-178.

Komariyah, Siti. dkk. 2017. "Pengembangan Model Pembangkit Listrik Tenaga Angin untuk Meningkatkan Kemampuan Berpikir Kritis". Makalah disajikan pada Prosiding Seminar Nasional Fisika., Jakarta, Oktober 2017.

Maharani, Meyrika. 2017. Pengembangan Alat Peraga pada Materi Usaha dan Energi untuk Melatihkan Keterampilan Proses Sains melalui Model Inquiry Discovery Learning (IDL) Terbimbing. Berkala IImiah Pendidikan Fisika, Vol.5 No.3

Mukminan. 2013 "Kurikulum 2013 pada Jenjang Pendidikan Dasar dan Menengah". Makalah disajikan pada Workshop Pengkajian Kurikulum Pendidikan Dasar dan Menengah, Yogyakarta, 25 Oktober 2013.

Mulyatiningsih, Endang. 2012. Metode Penelitian Terapan Bidang Pendidikan. Bandung: Alfabeta.

Neufeld, P., Mirzaei, O., Runco, M., \& Maw, S. (2017). Creativity in Design Engineers: Attitudes,Opinions and Potentially Influential Factors. Proceedings of the Canadian Engineering Education Association

Pramesty, R. I., \& Prabowo. 2013. "Pengembangan Alat Peraga KIT Fluida Statis Sebagai Media Pembelajaran Pada Sub Materi Fluida Statis di Kelas XI IPA SMA Negeri 1 Mojosari, Mojokerto". Jurnal Inovasi Pendidikan Fisika, Vol 2(3) : Hal 70-74.

Prasetyarini, Ayomi. 2013. "Pemanfaatan Alat Peraga IPA untuk Peningkatan Pemahaman Konsep Fisika pada Siswa SMP Negeri 1 Buluspesantren Kebumen Tahun Pelajaran 2012/2013 ". Radiasi : Jurnal Berkala Pendidikan Fisika. Vol 2 (1) : Hal 7-10.

Pujiati. 2004. Penggunaan Alat Peraga dalam Pembelajaran Matematika SMP,. Yogyakarta : PPPG Matematika.Putri, M.P dan Kurniawati, W. Pengembangan Alat Peraga Pemanasan Global Berbahan Bekas Pakai untuk Menanamkan Karakter Peduli Lingkungan. (online) (https://core.ac.uk, diakses pada 4 Oktober 2020).

Putra, M. I. S., Widodo, W., \& Jatmiko, B. (2016). the Development of Guided Inquiry Science Learning Materials To Improve Science Literacy Skill of Prospective MiTeachers. JPII, 5(1), 83-93. https://doi.org/10.15294/jpii.v5i1.5794

Religia, Racy. Hainur Rasyid Achmadi. 2017. Pengembangan KIT Sederhana Stirling Engine pada Materi Termodinamika sebagai Media Pembelajaran Fisika SMA. Jurnal Inovasi Pendidikan Fisika, Vol.06 No. 03 Hal.113-119

Riduwan. 2015. Dasar-Dasar Statistika. Bandung: Alfabeta.

Riyana, Cepi. 2008. Media Pembelajaran. Bandung :CV Wacana.

Riyana, Cepi, Susilana, Rudi. 2009. Media Pembelajaran: Hakikat,. Pengembangan, Pemanfaatan, dan Penilaian. Bandung: CV Wacana Prima.

Sugiyono. 2010. Metode Penelitian Pendekatan Kuantitatif, Kualitatif dan R\&D, Bandung: Alfabeta.

Swasono, Fajar. 2013. Pengembangan Alat Konversi Energi sebagai Alat Peraga Materi. Jurnal Pembelajaran Fisika UNILA, Vol.1 No.4.

Tedi, Arnoldus, dkk.2013. Pengembangan KIT pada Materi Pesawat Sederhana pada Siswa SMP Satu Atap 1 Kedondong. Jurnal Pembelajaran Fisika UNILA, Vol.1 No.7

Tegeh, Made Dkk. 2014. Model Penelitian Pengembangan. Yogyakarta: Graha IImu.

Yalcin, S. A., Turgut, U., \& Buyukkasai, E. (2014). The Effect of Project Based Learning on Science Undergraduates' Learning of Electricity, Attitude Towards Physics and Scientific Process Skills. International Online Journal of Education Sciences, 1(1), 81 105.

Zuhal.1988. Dasar Teknik Tenaga Listrik dan Elektronika Daya. Jakarta: Gramedia. 